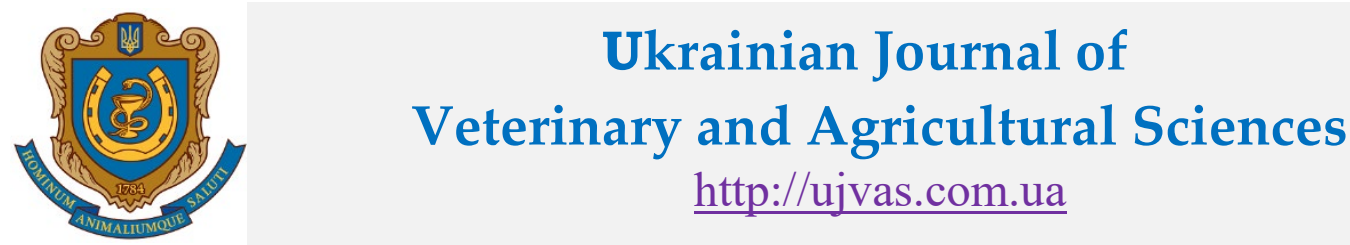

Stepan Gzhytskyi National University of Veterinary Medicine and Biotechnologies Lviv \begin{tabular}{l|l|l} 
original article & UDC 619:616-091.8:59 & doi: $\mathbf{1 0 . 3 2 7 1 8 / u j v a s 3 - 1 . 0 3}$
\end{tabular}

\title{
The effect of different doses of probiotic feed additives on hematologic indices and morphological structure of individual pig internal organs
}

\author{
M. Zhyla ${ }^{1}$, N. Shkodyak ${ }^{1}$, G. Kotsyumbas ${ }^{2}$, Y. Stronskyi ${ }^{2}$ O. Sobodosh ${ }^{1}$, M. Shkil ${ }^{2}$ \\ ${ }^{1}$ State Scientific-Research Control Institute of Veterinary Medicinal Products and Feed Additives, Donets'ka Str., 11, Lviv, \\ 79019, Ukraine \\ ${ }^{2}$ Stepan Gzhytskyi National University of Veterinary Medicine and Biotechnologies, Pekarska Str., 50, Lviv, 79010, Ukraine
}

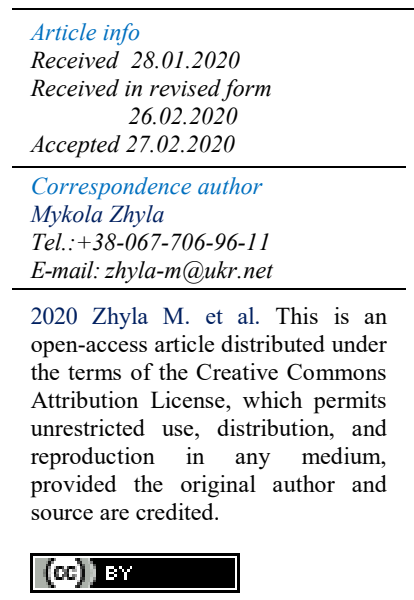

Contents

1. Introduction

2. Materials and methods.......... 13

3. Results and discussion .......

$\begin{array}{ll}\text { 3. Results and discussion ........ } & 14 \\ \text { 4. Conclusions ................. } & 19\end{array}$

References ..................... 19

\begin{abstract}
In order to improve the digestibility and absorption of feed, metabolic processes, growth and development of animals, increase the resistance of the body immunomodulatory agents, probiotics, prebiotics, combined enzymeprobiotic feed additives are widely used. The purpose of our work was to conduct comparative clinical trials of the effectiveness of the probiotic feed additive Probion-forte in terms of productivity, blood indices and histological structure of individual internal pigs organs during fattening. The researches were carried out on 120 piglets of big white breed at the age of 28 days, which were divided into 4 groups with 30 units in each one. The probiotics were added to feed in different concentrations in order to determine their efficiency and examine influence on piglets organism: the first group was given probiotic Probion-forte in dose of $1.0 \mathrm{~g} / \mathrm{kg}$ (10 weeks); the second one - Probion in dose of $1.0 \mathrm{~g} / \mathrm{kg}$ (6 weeks) and $0.5 \mathrm{~g} / \mathrm{kg}$ (4 weeks); the third one was given probiotic Bio Plus $2 \mathrm{~B}$ in dose of $0.4 \mathrm{~g} / \mathrm{kg}$ for 10 weeks; and the fourth one was a control group. The compound feed was provided according to norms recommended for big white breed taking into account age. On the 42 nd day ( 6 weeks) and on the $70^{\text {th }}$ day of test 10 units were selected for haematological, pathomorphological and microbiological tests. The productivity of animals of all studied groups was evaluated by the average daily gains, safety, feed conversion and slaughter output. The stabilized with EDTA piglets' blood was used for morphological studies, and blood serum - for biochemical studies. The clinical trials have shown that the application of Probion-forte, as a feed additive for fattening of piglets within 10 weeks after weaning, did not cause adverse reactions, was well tolerated by animals and contributed to the improvement of the processes of erythropoiesis and leucopoiesis, increased of serum total protein content. The increasing activity of serum transaminases indicated more intense metabolic processes in experimental animals' organism, which was confirmed by increase in average daily weight gains and slaughter output compared to control. In the microscopic examination of the thymus, spleen, lymph nodes, intestines, liver, the characteristic histological structure of the organs was preserved and indicated their active morphofunctional state throughout the study period. Morphometrically the increase in the height of the villi in the duodenum and the size of the thymus lobes in piglets, which were fed with probiotic feed additives was established. The efficiency and appropriateness of the application of these products was confirmed in the first and second experimental groups. However, the most significant difference was observed in piglets fed with Probion-forte for 10 weeks at a dose of $1.0 \mathrm{~g} / \mathrm{kg}$ of feed.
\end{abstract}

Key words: clinical trials, piglets, laboratory diagnosis, histostructure, duodenum, liver, thymus, spleen, lymph nodes, thymocytes, villus height.

\section{Citation:}

Zhyla, M., Shkodyak, N., Kotsyumbas, G., Stronskyi, Y., Sobodosh, O., \& Shkil, M. (2020). The effect of different doses of probiotic feed additives on hematologic indices and morphological structure of individual pig internal organs. Ukrainian Journal of Veterinary and Agricultural Sciences, 3(1), 13-20.

\section{Introduction}

Modern livestock farming is based on the genetic potential of animals, balanced feeding and appropriate conditions of keeping. In order to improve the digestibility and absorption of feed, metabolic processes, growth and development of animals, to increase the body's resistance, the immunomodulatory agents, probiotics, prebiotics, combined enzyme-probiotic feed additives and herbal remedies are widely used (Patterson \& Burkholder, 2003; Swiatkiewicz \&
Koreleski, 2007; Reshetnichenko et al., 2012; Ushakova et al., 2012).

In this aspect, a significant advantage is given to the probiotic cultures of microorganisms. Probiotics have a positive effect on the bird's body, as they promote the recovery of digestion, biological status, immune response, and increase the effectiveness of vaccinations. The use of probiotics significantly reduces the costs for the treatment of diseases, increases productivity, and improves the quality of livestock products. The market for drugs in this group is actively developing and replenishing every time with new 
samples of domestic and foreign production (Griggs \& Jacob, 2005; Lisova et al., 2013; Bliznetsov \& Tokarev, 2013; Zhyla et al., 2014; Kotsyumbas et al., 2014).

One of the key and mandatory prerequisites for the creation and testing of new veterinary products, feed additives, both in the context of compliance with national legislation and the requirements of the international community for their registration, is conducting of preclinical and clinical trials in compliance with Good Clinical Practice (GCP) requirements. Criteria for evaluating the efficiency and safety of the test products should not be limited only to safety and productivity but should also include characteristics of the morphofunctional state of the target animal species based on laboratory diagnosis (Anadon et al., 2006; Kocjumbas, \& Lemishevskij, 2013; Zhyla, 2017; Todoriuk et al., 2018; Gutyj et al., 2018; Zhyla et al., 2019; Patereha et al., 2019).

The purpose of our work was to conduct comparative clinical trials of the efficiency of the probiotic feed additive "Probion-forte" in terms of productivity, blood indices and histological structure of individual internal organs of piglets during fattening.

\section{Materials and methods}

We used probiotic feed additives: Probion-forte which includes Bacillus subtilis, not less than $1 \times 10^{8} \mathrm{CFU} / \mathrm{g}$ B. coagulans not less than $1 \times 10^{8} \mathrm{CFU} / \mathrm{g}$ and Bio Plus $2 \mathrm{~B}$ containing $B$. subtilis, not less than $2 \times 10^{8} \mathrm{CFU} / \mathrm{g}$.

The researches were conducted on the base of Research and Production Center "Komarnyvsky" (Komarno village, Gorodotsky district Lviv region) with 120 piglets of Big white breed at the age of 28 days, which were divided into 4 groups. In order to determine the efficiency of application, both probiotic feed additives were given to piglets in different concentrations together with feed. The first group was given probiotic Probion-forte in dose of $1 \mathrm{~g} / \mathrm{kg}$ (10 weeks); the second one - Probion-forte in dose of $1 \mathrm{~g} / \mathrm{kg}$ (6 weeks) and $0.5 \mathrm{~g} / \mathrm{kg}$ (4 weeks); the third one was given probiotic Bio Plus 2B, in dose of $0.4 \mathrm{~g} / \mathrm{kg}$ for 10 weeks; and the fourth one was a control group. Each group contained 30 units. The compound feed was provided according to norms recommended for Big white breed taking into account age. Veterinary sanitary processing was conducted according to growth scheme. The dynamics of live weight of pigs was examined by means of method of individual weighing according to scheme on the $1^{\text {st }}, 14^{\text {th }}, 28^{\text {th }}, 42^{\text {nd }}, 56^{\text {th }}$ and $70^{\text {th }}$ day. Animals were kept in cages with 15 units in each one with free access to feed and water.

Experiments with animals were carried out in accordance with the rules adopted by the European Convention for the Protection of Vertebrate Animals Used for Experimental and other Scientific Purposes (Strasbourg, 1986).

On the $42^{\text {nd }}$ day of experiment ( 6 weeks) from $1^{\text {st }}, 3^{\text {rd }}$ and $4^{\text {th }}$ group and on the $70^{\text {th }}$ day of test (10 weeks) from $1^{\text {st }}, 2^{\text {nd }}$, $3^{\text {rd }}$ and $4^{\text {th }}$ group 10 units were selected for haematological, pathomorphological and microbiological researches. The productivity of the animals of all studied groups was evaluated by average daily weight gains, safety, feed conversion and slaughter output.

The stabilized EDTA blood of piglets was used for morphological studies, and blood serum - for biochemical studies. Blood was collected from animal's cranial hollow vein. Determination of the investigated parameters was carried out according to generally accepted methods, adapted in the Laboratory of Clinical Biological Research of the State Scientific Research Control Institute of Veterinary Medicinal Products and Fodder Additives, using appropriate instruments and test-kits (Kocjumbas \& Lemishevskij, 2013).

After slaughter the animals were subjected to complete pathologic anatomical dissection, with the selection of material for histological and morphometric studies. Internal organs were weighed, their weight coefficients were determined. Material (pieces of duodenum, caecum, liver, thymus, spleen and lymph nodes) was fixed in neutralized $10 \%$ formalin, with following paraffin pouring. Paraffin cuts were stained with haematoxylin-eosin (Merkulov, 1969).

Microscopy was conducted by means of microscope OLIMPUS CX-41 and morphometric program DP-SOFT.

The obtained results were statistically processed, estimating the probability of difference of indicators on the Student's test. The arithmetic mean (M), the mean error of the arithmetic mean $(\mathrm{m})$, and the significance criterion $(\mathrm{P})$ were determined. Numerical data were processed using Microsoft Excel XP and Statistica 10. The difference between values at which the probability of difference $(\mathrm{P})$ did not exceed 0.05 was taken as a statistically significant result.

\section{Results and discussion}

During the whole test period any deviations concerning clinical condition of piglets not observed. Piglets of all groups were active, diseases and death were not registered. There were only two cases of diarrhea in the control group of piglets. After medical assistance to these animals, all signs of intestinal disorders disappeared for 3-5 days.

The test showed that probiotics contribute to better digestion of feed, compared with the control group, as well as a gradual increase in weight gain throughout the growing period (70 days). Thus, in $1^{\text {st }}$ group at average live weight of the piglets of $38.7 \mathrm{~kg}$, feed conversion was equal to 2.24 ; in the $2^{\text {nd }}$ group at average live weight of $38,4 \mathrm{~kg}$ feed conversion was equal to 2.26 ; in the $3^{\text {rd }}$ group at animal's average live weight of $37.1 \mathrm{~kg}$ feed conversion - 2.37; in the control group at the average live weight of $35.4 \mathrm{~kg}$ feed conversion was 2.5 .

We evaluated average weight gain per day, as it is the most objective index of growth intensity. As data show, the average weight gain in studied groups was higher, than in control one during whole test period. The most significant difference in indices was observed on the $70^{\text {th }}$ day of test, at the pigs' age of 98 days. Thus, average daily weight gains in the $1^{\text {st }}$ group were higher than in control one by $86 \mathrm{~g}$, and in $2^{\text {nd }}$ and $3^{\text {rd }}$ ones - by 76.0 and 54.0, respectively. A more pronounced difference in the body mass index of pigs was at the end of the fattening period (210 days) and was $127.4 \pm$ $2.9 \mathrm{~kg}$ in the $1^{\text {st }}$ group and was $13.34 \%$ greater $(\mathrm{P}<0.01)$, in groups $2^{\text {nd }}$ and $3^{\text {rd }}$ respectively: $125.1 \pm 3.2 \mathrm{~kg}$ by $11.2 \%$ $(\mathrm{P}<0.01) ; 119.2 \pm 2.3 \mathrm{~kg}$ by $6.05 \%$. Whereas in the control group, the body weight of the pigs was $112.4 \pm 3.1 \mathrm{~kg}$. The carcass yield was $69.7 \%$ in the $1^{\text {st }}$ group; $68.3 \%$; in the $2^{\text {nd }}$ group; $68.0 \%$ in the $3^{\text {rd }}$ group and control $-67.2 \%$.

As data show (table 1), morphological indices of blood of treated groups were within physiological norm for animals of this age. Analysis of results shows the increasing of haemoglobin concentration on the $42^{\text {nd }}$ day of test in $1^{\text {st }}$ and $3^{\text {rd }}$ groups and on the $70^{\text {th }}$ day - in the $1^{\text {st }}$ one in comparison with control group. Increase of haemoglobin level has posi- 
tive influence. We also observed increase of erythrocyte quantity and haematocrite in groups that were given Probion-forte during 10 days (table 1). Analysing of leukogram we observed the increase of relative number of lymphocytes and decrease of eosinophiles in the $1^{\text {st }}$ group in comparison with control group, on the $70^{\text {th }}$ day of test (table 1).

Table 1

Morphological indices of blood of piglets at application of probiotic feed additive $(\mathrm{M} \pm \mathrm{m}, \mathrm{n}=10)$

\begin{tabular}{|c|c|c|c|}
\hline Indices & Groups & $\begin{array}{c}42^{\text {nd }} \text { day of } \\
\text { test }\end{array}$ & $\begin{array}{c}70^{\text {th }} \text { day of } \\
\text { test }\end{array}$ \\
\hline \multirow{4}{*}{$\begin{array}{l}\text { Haemoglobin, } \\
\text { g/l }\end{array}$} & 1 & $131.1 \pm 4.1$ & $132.0 \pm 1.8 *$ \\
\hline & 2 & - & $126.3 \pm 1.7$ \\
\hline & 3 & $133.2 \pm 5.6$ & $123.2 \pm 1.4$ \\
\hline & 4 & $117.1 \pm 4.9$ & $116.5 \pm 1.1$ \\
\hline \multirow{4}{*}{$\begin{array}{c}\text { Erythrocytes, } \\
10^{12} / 1\end{array}$} & 1 & $5.5 \pm 0.2$ & $7.6 \pm 0.4^{*}$ \\
\hline & 2 & - & $7.0 \pm 0.5^{*}$ \\
\hline & 3 & $5.6 \pm 0.3$ & $6.4 \pm 0.2$ \\
\hline & 4 & $6.1 \pm 0.2$ & $6.0 \pm 0.3$ \\
\hline \multirow{4}{*}{$\begin{array}{c}\text { Haematocrite, } \\
\%\end{array}$} & 1 & $39.8 \pm 2.4$ & $42.5 \pm 1.1^{*}$ \\
\hline & 2 & - & $39.8 \pm 1.2^{*}$ \\
\hline & 3 & $38.3 \pm 0.9$ & $40.3 \pm 1.9^{*}$ \\
\hline & 4 & $37.0 \pm 1.7$ & $35.0 \pm 1.2$ \\
\hline \multirow{4}{*}{$\begin{array}{c}\text { Leukocytes, } \\
10^{9} / 1\end{array}$} & 1 & $12.5 \pm 1.7$ & $15.1 \pm 1.7$ \\
\hline & 2 & - & $15.0 \pm 1.7$ \\
\hline & 3 & $13.7 \pm 1.8$ & $14.9 \pm 1.8$ \\
\hline & 4 & $14.6 \pm 1.4$ & $14.2 \pm 2.1$ \\
\hline \multirow{4}{*}{ Basophils, \% } & 1 & $0.3 \pm 0.3$ & $0.8 \pm 0.3$ \\
\hline & 2 & - & $0.2 \pm 0.2$ \\
\hline & 3 & $0.6 \pm 0.3$ & $0.5 \pm 0.4$ \\
\hline & 4 & $0.3 \pm 0.2$ & 0 \\
\hline \multirow{4}{*}{ Eosinophils, \% } & 1 & $5.4 \pm 0.5$ & $2.6 \pm 0.5^{*}$ \\
\hline & 2 & - & $3.5 \pm 0.9 *$ \\
\hline & 3 & $7.3 \pm 2.7$ & $3.5 \pm 1.3 *$ \\
\hline & 4 & $10.0 \pm 1.8$ & $8.7 \pm 0.8$ \\
\hline \multirow{4}{*}{$\begin{array}{c}\text { Lymphocytes, } \\
\%\end{array}$} & 1 & $49.8 \pm 2.0$ & $55.6 \pm 0.9^{*}$ \\
\hline & 2 & - & $45.3 \pm 1.0$ \\
\hline & 3 & $44.0 \pm 1.2$ & $44.0 \pm 1.2$ \\
\hline & 4 & $42.7 \pm 1.2$ & $44.0 \pm 1.2$ \\
\hline \multirow{4}{*}{ Monocytes, \% } & 1 & $5.2 \pm 0.4$ & $3.6 \pm 0.7$ \\
\hline & 2 & - & $4,0 \pm 0,7$ \\
\hline & 3 & $4.3 \pm 0.4$ & $3.0 \pm 0.7$ \\
\hline & 4 & $3.3 \pm 0.8$ & $4.7 \pm 0.8$ \\
\hline \multirow{4}{*}{$\begin{array}{c}\text { Banded } \\
\text { neutrophils, \% }\end{array}$} & 1 & $4.6 \pm 1.0$ & $2.8 \pm 0.7^{*}$ \\
\hline & 2 & - & $5.0 \pm 0.4$ \\
\hline & 3 & $6.0 \pm 1.2$ & $2.3 \pm 0.3$ \\
\hline & 4 & $6.0 \pm 1.2$ & $5.0 \pm 0.6$ \\
\hline \multirow{4}{*}{$\begin{array}{c}\text { Segmented } \\
\text { neutrophils, \% }\end{array}$} & 1 & $34.4 \pm 0.9$ & $35.4 \pm 1.5$ \\
\hline & 2 & - & $39.0 \pm 0.7$ \\
\hline & 3 & $38.0 \pm 2.3$ & $39.5 \pm 1.0$ \\
\hline & 4 & $34.7 \pm 3.1$ & $37.3 \pm 1.5$ \\
\hline
\end{tabular}

Here and further: $*_{-} \mathrm{P} \leq 0.05 ; *^{*}-\mathrm{P} \leq 0.01$ compared to control

With regard to the indicators characterizing the immunophysiological state, on the $70^{\text {th }}$ day of the experiment in all groups we observed an increase in the total protein concentration in the serum and its albumin fraction, which indicates the intensity of piglets' protein metabolism (Table 2). On the $70^{\text {th }}$ day of testing, we observed positive changes in the number of circulating immune complexes in the serum, namely a $30.6 \%$ decrease in the 1 st group and $44.7 \%$ in the $2^{\text {nd }}$ group, compared with the control group, and almost twice on the $42^{\text {nd }}$ day of experiment (table 2).

Analysis of received data concerning biochemical indices of blood serum (table 3 ) showed that on the $42^{\text {nd }}$ day of test, activity of alkaline phosphatase of all treated groups was higher than on the $70^{\text {th }}$ day. It is connected with intensive growing of young stock, since activity of alkaline phosphatase is known to depend on speed of animal growth. Thus, on the $70^{\text {th }}$ day of the experiment we detected increase of activity of alkaline phosphatase in blood serum in the $1^{\text {st }}$ and $2^{\text {nd }}$ group, which were given Probion-forte, in comparison with control group, by $16.4 \%$ and $15.2 \%$, respectively. Significant decrease of enzyme activity in blood meant normalized influence of probiotic on metabolic processes in organism.

Table 2

Indices of immunophisiological state of piglets at application of probiotic feed additives $(\mathrm{M} \pm \mathrm{m}, \mathrm{n}=10)$

\begin{tabular}{|c|c|c|c|}
\hline Indices & Groups & $\begin{array}{c}42^{\text {nd }} \text { day of } \\
\text { test }\end{array}$ & $\begin{array}{c}70^{\text {th }} \text { day of } \\
\text { test }\end{array}$ \\
\hline \multirow{4}{*}{$\begin{array}{l}\text { Total protein, } \\
\text { g/l }\end{array}$} & 1 & $60.9 \pm 1.3$ & $67.8 \pm 3.1$ \\
\hline & 2 & - & $69.3 \pm 1.8$ \\
\hline & 3 & $64.6 \pm 1.4$ & $66.4 \pm 3.1$ \\
\hline & 4 & $63.6 \pm 1.6$ & $63.0 \pm 1.1$ \\
\hline \multirow{4}{*}{ Albumin, \% } & 1 & $27.2 \pm 1.4$ & $36.1 \pm 1.4$ \\
\hline & 2 & - & $34.6 \pm 2.6$ \\
\hline & 3 & $33.7 \pm 2.2$ & $32.5 \pm 2.1$ \\
\hline & 4 & $33.1 \pm 1.8$ & $34.5 \pm 3.1$ \\
\hline \multirow{4}{*}{$\alpha_{1}$-globulins, $\%$} & 1 & $12.3 \pm 4.2$ & $2.1 \pm 0.6$ \\
\hline & 2 & - & $2.3 \pm 0.2$ \\
\hline & 3 & $6.5 \pm 2.6$ & $2.9 \pm 0.2$ \\
\hline & 4 & $4.7 \pm 0.7$ & $3.1 \pm 0.8$ \\
\hline \multirow{4}{*}{$\underset{\%}{\alpha_{2}-\text { globulins, }}$} & 1 & $18.4 \pm 2.1$ & $14,7 \pm 1,3$ \\
\hline & 2 & - & $16.2 \pm 1.0$ \\
\hline & 3 & $22.2 \pm 5.3$ & $16.7 \pm 1.1$ \\
\hline & 4 & $12.1 \pm 1.6$ & $19.2 \pm 1.0$ \\
\hline \multirow{4}{*}{$\beta$-globulins, $\%$} & 1 & $14.7 \pm 1.6$ & $10.1 \pm 0.5$ \\
\hline & 2 & - & $15.7 \pm 0.6$ \\
\hline & 3 & $13.9 \pm 2.4$ & $16.2 \pm 2.2$ \\
\hline & 4 & $18.4 \pm 1.1$ & $16.2 \pm 0.5$ \\
\hline \multirow{4}{*}{$\gamma$-globulins, $\%$} & 1 & $26.1 \pm 2.6$ & $37.8 \pm 0.7 *$ \\
\hline & 2 & - & $31.2 \pm 1.0^{*}$ \\
\hline & 3 & $23.8 \pm 1.0$ & $28.4 \pm 1.3$ \\
\hline & 4 & $32.1 \pm 1.2$ & $27.9 \pm 1.2$ \\
\hline \multirow{4}{*}{$\begin{array}{l}\text { Phagocytic } \\
\text { activity of neu- } \\
\text { trophils, } \%\end{array}$} & 1 & $19.0 \pm 1.0$ & $26.1 \pm 0.5^{* *}$ \\
\hline & 2 & - & $19.3 \pm 0.4$ \\
\hline & 3 & $22.0 \pm 1.0$ & $22.4 \pm 1.0$ \\
\hline & 4 & $18.0 \pm 0.4$ & $19.5 \pm 0.4$ \\
\hline \multirow{4}{*}{$\begin{array}{l}\text { Phagocytic } \\
\text { index }\end{array}$} & 1 & $14.2 \pm 0.3$ & $18.0 \pm 0.2 * *$ \\
\hline & 2 & - & $14.6 \pm 0.4^{*}$ \\
\hline & 3 & $11.4 \pm 1.0$ & $13.6 \pm 1.0 *$ \\
\hline & 4 & $13.2 \pm 0.3$ & $12.0 \pm 0.4$ \\
\hline \multirow{4}{*}{$\begin{array}{c}\text { Circulating } \\
\text { immune com- } \\
\text { plexes, U/100 } \\
\text { ml }\end{array}$} & 1 & $20.2 \pm 5.9$ & $11.8 \pm 2.7 * *$ \\
\hline & 2 & - & $9.4 \pm 1.2 *$ \\
\hline & 3 & $25.5 \pm 2.6$ & $19.0 \pm 3.4$ \\
\hline & 4 & $24.0 \pm 4.7$ & $17.0 \pm 2.4$ \\
\hline
\end{tabular}

As shown by the experimental data (table 3), in the body of piglets that received probiotics, the processes of transam- 
ination of alanine and aspartate by aminotransferases were carried out with different intensity. In particular, on day 70 of testing, we found a higher activity of serum alanine and aspartate aminotransferase in group 1 by $15.1 \%$ and $20.5 \%$, respectively, compared with the control group. In group 3, we observed a tendency to increase the activity of the above-mentioned enzymes.

Given the fact that the activity of aminotransferases in the blood is associated with their participation in the process of protein synthesis, the use of free amino acids in the energetic and plastic processes in the tissues of intensively growing organism, the revealed changes in the enzymatic activity confirm the activating effect of Probion-forte on the process of reamination of free amino acids, as well as the growth and development of young animals. With regard to indicators of total cholesterol, urea and creatinine content, no significant differences were found between the treated and control groups.

Analyzing the dynamics of the weights of the internal organs, we concluded that an increase in body weight caused an increase in the weight of the internal weight. The coefficients of the internal organs on day $70^{\text {th }}$ of the experiment were shown in table 4 . As shown in the table, the coefficients of thymus mass were significantly higher in the $1^{\text {st }}$ and $2^{\text {nd }}$ groups, compared with the control.

Macroscopic study of thymus showed that in all experimental groups on the $42^{\text {nd }}$ and $70^{\text {th }}$ day thymus retained a typical anatomical structure, it was light pink in color and soft consistency. At cross cut typical organ architectonics is well-expressed.
Table 3

Biochemical indices of blood serum of piglets at application of probiotic feed additives $(\mathrm{M} \pm \mathrm{m}, \mathrm{n}=10)$

\begin{tabular}{|c|c|c|c|}
\hline Indices & Groups & $\begin{array}{c}42^{\text {nd }} \text { day of } \\
\text { test }\end{array}$ & $\begin{array}{c}70^{\text {th }} \text { day of } \\
\text { test }\end{array}$ \\
\hline \multirow{4}{*}{$\begin{array}{c}\text { Alanine } \\
\text { aminotransferase, } \\
(\mathrm{ALT}) \mu \mathrm{kat} / \mathrm{l}\end{array}$} & 1 & $0.36 \pm 0.04^{*}$ & $0.38 \pm 0.01 *$ \\
\hline & 2 & - & $0.35 \pm 0.01$ \\
\hline & 3 & $0.38 \pm 0.05$ & $0.36 \pm 0.01$ \\
\hline & 4 & $0.32 \pm 0.01$ & $0.33 \pm 0.01$ \\
\hline \multirow{4}{*}{$\begin{array}{c}\text { Aspartate } \\
\text { aminotransferase, } \\
(\mathrm{AST}) \mu \mathrm{kat} / \mathrm{l}\end{array}$} & 1 & $0.38 \pm 0,03$ & $0.47 \pm 0.02 *$ \\
\hline & 2 & - & $0.40 \pm 0.02 *$ \\
\hline & 3 & $0.37 \pm 0.04$ & $0.44 \pm 0.02 *$ \\
\hline & 4 & $0.39 \pm 0.05$ & $0.39 \pm 0.01$ \\
\hline \multirow{4}{*}{$\begin{array}{l}\text { Alkaline phospha- } \\
\text { tase, } \mu \mathrm{kat} / 1\end{array}$} & 1 & $2.31 \pm 0.02$ & $1.72 \pm 0.01$ \\
\hline & 2 & - & $1.81 \pm 0.03$ \\
\hline & 3 & $1.63 \pm 0.08$ & $1.91 \pm 0.02$ \\
\hline & 4 & $2.41 \pm 0.06$ & $1.28 \pm 0.08$ \\
\hline \multirow{4}{*}{$\begin{array}{l}\text { Total cholesterol, } \\
\text { mmole/l }\end{array}$} & 1 & $3.90 \pm 0.17$ & $6.35 \pm 0.21$ \\
\hline & 2 & - & $6.57 \pm 0.40$ \\
\hline & 3 & $4.43 \pm 0.19$ & $6.80 \pm 0.50$ \\
\hline & 4 & $4.72 \pm 0.16$ & $7.00 \pm 0.26$ \\
\hline \multirow{4}{*}{ Urea, mmole/1 } & 1 & $5.10 \pm 0.27$ & $5.19 \pm 0.22$ \\
\hline & 2 & - & $5.27 \pm 0.38$ \\
\hline & 3 & $6.06 \pm 0.32$ & $5.57 \pm 0.25$ \\
\hline & 4 & $5.63 \pm 0.34$ & $5.55 \pm 0.11$ \\
\hline \multirow{4}{*}{$\begin{array}{l}\text { Creatinine, } \\
\mu \text { mole/l }\end{array}$} & 1 & $204.0 \pm 7.0$ & $215.0 \pm 6.4$ \\
\hline & 2 & - & $224.0 \pm 5.8$ \\
\hline & 3 & $201.1 \pm 5.0$ & $214.0 \pm 5.7$ \\
\hline & 4 & $206.5 \pm 7.3$ & $236.0 \pm 4.0$ \\
\hline
\end{tabular}

Table 4

Coefficients of internal organ weight at application probiotic feed additives on the $70^{\text {th }}$ day of test $(\mathrm{M} \pm \mathrm{m}, \mathrm{n}=5)$

\begin{tabular}{lcccc}
\hline \multicolumn{1}{c}{ Indices } & $1^{\text {st }}$ group & $2^{\text {nd }}$ group & $3^{\text {rd }}$ group & $4^{\text {th }}$ group \\
\hline Liver & $2.65 \pm 0.12$ & $2.47 \pm 0.11$ & $2.27 \pm 0.09$ & $2.59 \pm 0.10$ \\
Kidneys & $0.5 \pm 0.03$ & $0.49 \pm 0.03$ & $0.43 \pm 0.04$ & $0.39 \pm 0.06$ \\
Heart & $0.53 \pm 0.04$ & $0.55 \pm 0.05$ & $0.57 \pm 0.04$ & $0.43 \pm 0.02$ \\
Lungs & $1.42 \pm 0.13$ & $1.37 \pm 0.11$ & $1.48 \pm 0.09$ & $1.32 \pm 0.06$ \\
Thymus & $0.54 \pm 0.03^{*}$ & $0.58 \pm 0.04^{*}$ & $0.48 \pm 0.05$ & $0.45 \pm 0.03$ \\
Spleen & $0.24 \pm 0.02$ & $0.21 \pm 0.03$ & $0.22 \pm 0.02$ & $0.21 \pm 0.03$ \\
\hline
\end{tabular}

Microscopic study of the thymus showed that the lobular structure was preserved in all experimental groups on the $42^{\text {nd }}$ and $70^{\text {th }}$ days. The segments are preferably polygonal in shape, some of which were extracted from the control group. The segments of the thymus were divided into the central medulla and peripheral cortex in all treated groups. The cortical part occupied most of the segment; the smaller part of the segment was occupied by the medullary part. The bark of segments of the thymus of the 1 st and $2^{\text {nd }}$ groups was tightly occupied by thymocytes of different size. Brain population density was significantly lower. Corpuscles of Hassall of different sizes and round form localized in medulla (Fig. 1-3).

On the $70^{\text {th }}$ day of experiment we detected more significant difference in histological structure of thymus in all studied groups. A more significant difference in the histological structure of the thymus was noted at $70^{\text {th }}$ day. Thus, the average thymus lobes were $910.2 \pm 251 \mu \mathrm{m}(\mathrm{P}<0.01)$, in the $1^{\text {st }}$ group; $872.4 \pm 23.5 \mu \mathrm{m}$ in the $2^{\text {nd }}$ group; $790.6 \pm$
$19.9 \mu \mathrm{m}$ in the $3^{\text {rd }}$ group (control $761.3 \pm 21.4 \mu \mathrm{m}$ ). The ratio between parenchyma and thymic stroma in groups was: 9.83:1; 9.02:1; 9.11:1 (control 8.26:1).

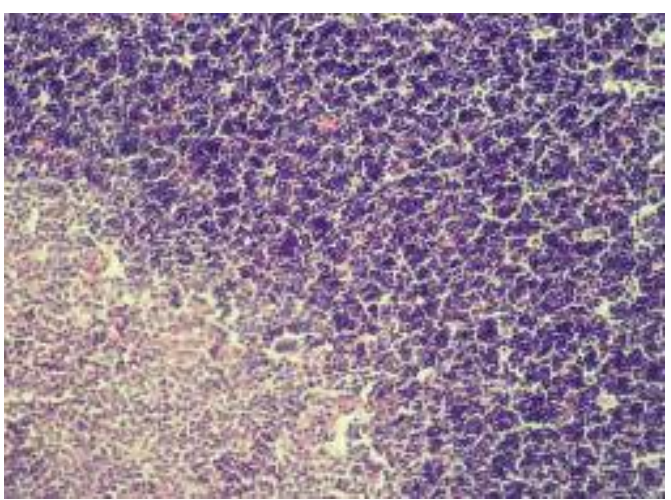

Fig. 1. Piglet thymus, the $1^{\text {st }}$ group, the $70^{\text {nd }}$ day of test. Division into cortical portion and medullary portion is preserved. H\&E. x 100 


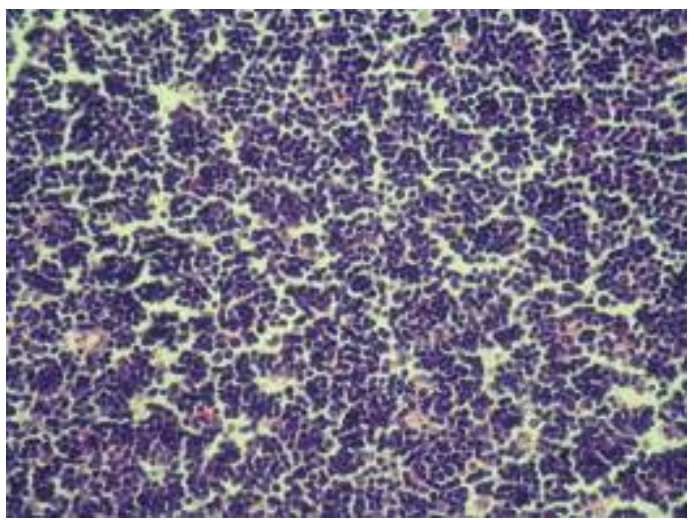

Fig. 2. Piglet thymus, the $1^{\text {st }}$ group, the $70^{\text {th }}$ day of test. Cortex is densely populated by thymocytes. H\&E. x 200

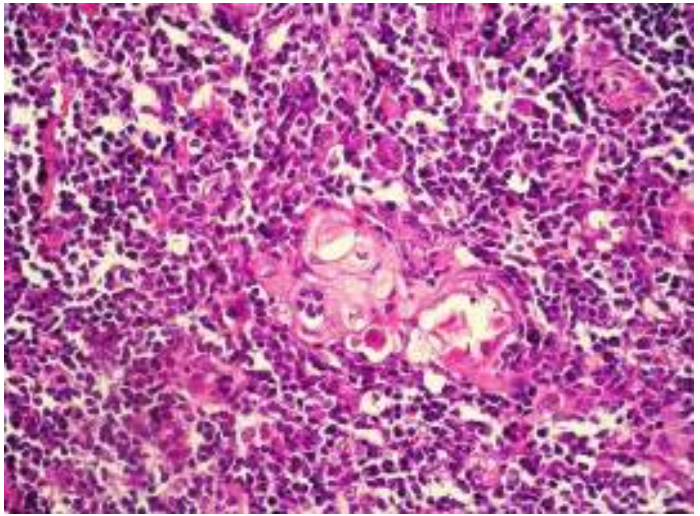

Fig. 3. Piglet thymus, the $2^{\text {nd }}$ group, the $70^{\text {th }}$ day of test.

Formed corpuscles of Hassall in medulla. H\&E. x 200

Decrease in thymocyte number was observed in thymus of piglets from control group. Thus, in control group cortical portion occupied smaller part of segment, larger part of segment was occupied by medullary portion. Subcapsular zone of cortex is represented by 2-3 rows of lymphocytes and lymphoblasts. We observed thickening of interlobular connective tissue with fat deposits. The decrease in thymocyte number in cortex was observed. The macrophages with phagocytic thymocytes or their fragments were detected (Fig. 4).

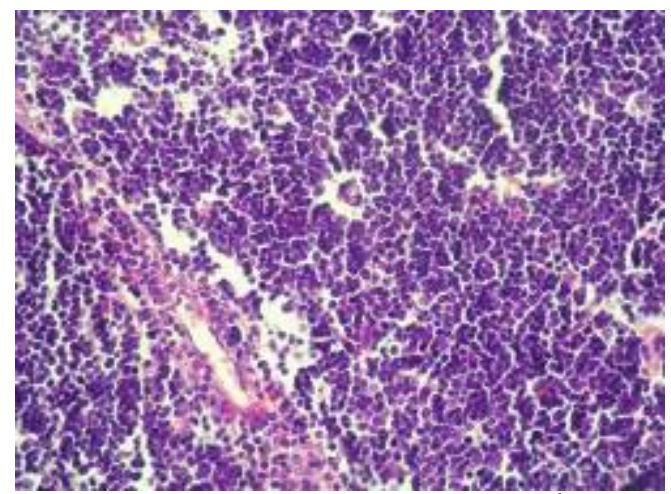

Fig. 4. Piglet thymus, control group, the $70^{\text {th }}$ day of test. Decrease in thymocyte number in cortex. H\&E. $x 200$

Electron microscopic examination of the thymus of the control group of animals revealed cellular elements of apoptosis, and in the experimental groups were clearly structured thymocytes with large nuclei rich in chromatin containing from one to several nucleoli. The cytoplasm is narrow, with a small amount of organelles (Fig. 5, 6).

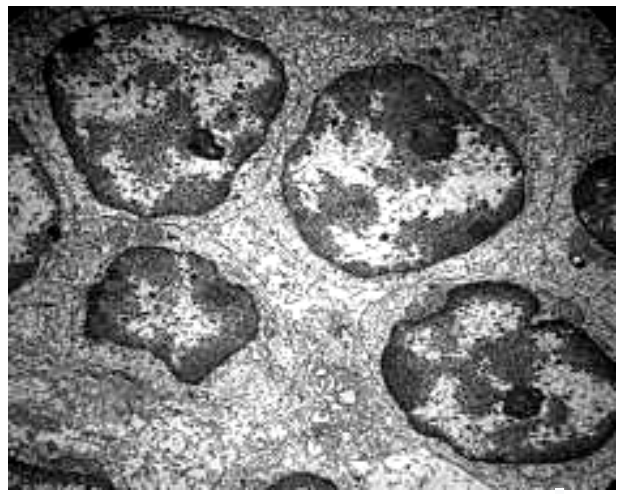

Fig. 5. Electronogram of thymocytes of pigs, $1^{\text {st }}$ group, the $70^{\text {nd }}$ day of test. $x 6000$

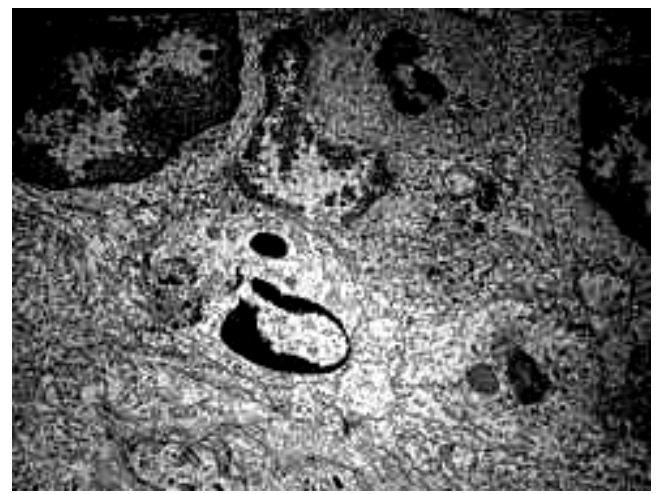

Fig. 6. Electronogram. Apoptosis of cells in the thymus of piglets control group, the $70^{\text {nd }}$ day of test. x 6000

Spleen in all treated groups on the $42^{\text {nd }}$ and $70^{\text {th }}$ day of experiment preserved typical anatomical form, it was of grey-blue colour with violet staining and pasty consistency, with rims being acute and capsule being elastic. At cross cut typical structure is preserved, pulp scraper is slight or absent.

Microscopic structure of spleen is preserved in all experimental groups. Division into white and red pulp is expressed. Lymph nodes (follicles) are of elongated form and of small and middle sizes, localized around central arteries. Follicles with germinative centres were observed in groups of piglets that were given probiotics. Cell composition of follicles is presented by small lymphocytes, lymphoblasts and plasmocytes. Density of cell population was significantly higher in the $1^{\text {st }}$ and $2^{\text {nd }}$ groups than in control one, especially on the $70^{\text {th }}$ day of test (Fig. 7).

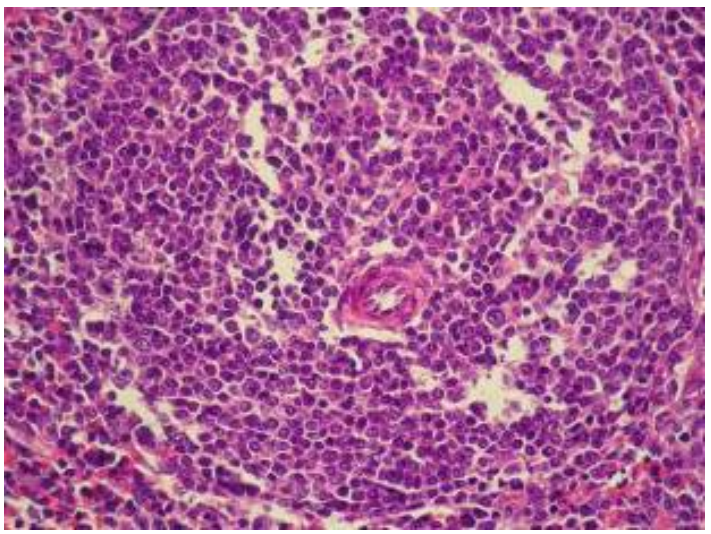

Fig. 7. Cell composition of spleen follicle, the $1^{\text {st }}$ group the $70^{\text {nd }}$ day of test. H\&E. x 200 
The lymph nodes of jejunum intestinal in all groups were not enlarged, of light pink colour and at cross cut they were wet. Microscope study showed that cortex and medulla were well-expressed as well as paracortical area. Cortex occupied larger part of thymus segment, medulla - smaller one. In the $1^{\text {st }}$ and $2^{\text {nd }}$ group lymphoid follicles are well-formed, boundaries are clear with reactive cores, we observed larger number in these two groups, than in the $3^{\text {rd }}$ and $4^{\text {th }}$ groups (Fig. 8, 9). Lymph nodes of piglets, that were not given probiotics, suffered from devastation of lymph follicles by cell elements, especially on the $70^{\text {th }}$ day of test (Fig. 10).

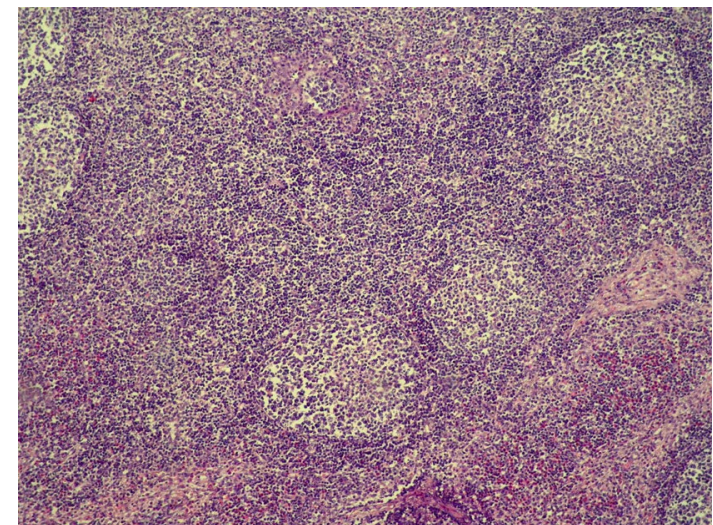

Fig. 8. Piglet lymph node, the $1^{\text {st }}$ group, the $70^{\text {th }}$ day of test. Lymphoid follicles with reactive cores in cortex. H\&E. x 100

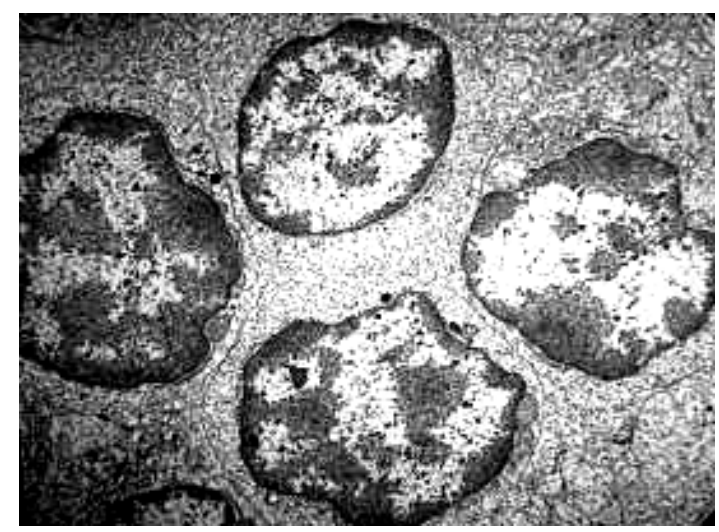

Fig. 9. Electronogram of lymphocytes of paracortical lymphatic zone of pigs, $1^{\text {st }}$ group, the $70^{\text {nd }}$ day of test. x 6000

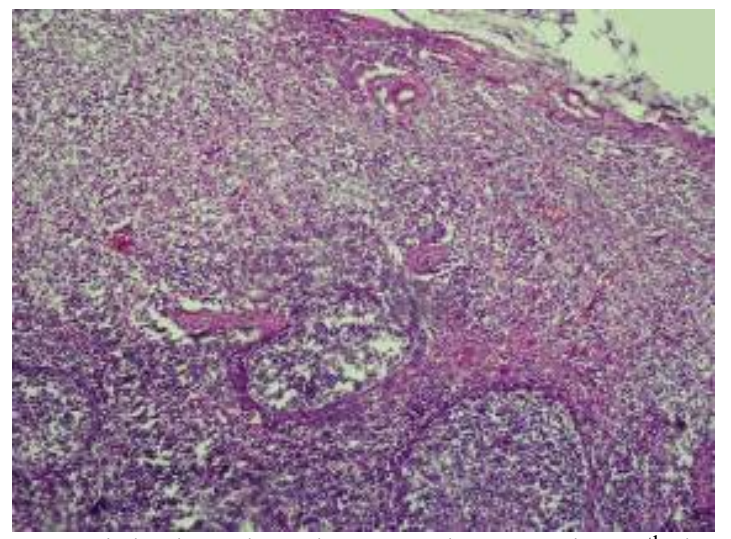

Fig. 10. Piglet lymph node, control group, the $70^{\text {th }}$ day of test. Cell devastation of lymphoid follicles. H\&E. x 100

Histological tests of duodenum showed that it consists of three membranes: mucous, muscular and serous. Above surface of mucous membrane there are gut villi in form of leaves of different forms and sizes (Fig. 11). Intestinal villi in all treated groups are not high, covered by cylindrical epithelium. There were also isolated parts of plica that resemble low cylindrical villi or papillae foliatae with rounded rims. Enterocytes (intestinal absorptive cells) had wellexpressed limbus strigillatus on apical surface, elongated nuclei were situated in basal cytoplasm. At the bottom of villi there were crypts. Duodenum glands were distinctly formed, localizing in submucous layer.

Histological study of piglets' duodenum from the $1^{\text {st }}$ and $2^{\text {nd }}$ groups, that were given probiotic Probion-forte in dose of 1 and $1-0.5 \mathrm{~g} / \mathrm{kg}$ of feed, showed that villi were homogeneous and higher than in control group, some of them were long and thin, other - big, in the form of leaves. Villi were covered by one-layer cylindrical epithelium (enterocytes), among which we observed goblet cells. Crypts represented branching of epithelial layer, they are situated from the bottom of villi to muscular plate of mucous membrane. Crypt depth was within 25 and $35 \mu \mathrm{m}$. Submucous base contained duodenum glands, blood vessels.

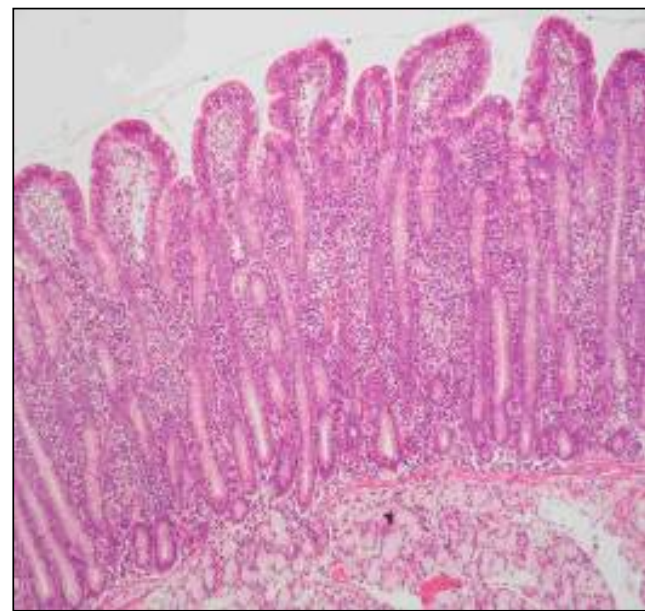

Fig. 11. Piglet duodenum. The $1^{\text {st }}$ group, the $70^{\text {th }}$ day of test. H\&E. $x 100$

Characterising villus height of duodenum in all groups on the $42^{\text {nd }}$ day of test, we have not observed significant difference. Some correlation of these indices was observed on the $70^{\text {th }}$ day of test (age of piglets -98 days).

In duodenum of piglets from the $1^{\text {st }}$ group villus height amounted to $488.32 \mu \mathrm{m}$ that was longer than the height of the villus in duodenum of piglets from the $4^{\text {th }}$ (control) group by $35.55 \mu \mathrm{m}$. The same situation was with piglets from the $2^{\text {nd }}$ and the $3^{\text {rd }}$ group. Villus height in duodenum of piglets from these two groups had increased by $25.35 \mu \mathrm{m}$ and by $20.35 \mu \mathrm{m}$ (in comparison with the $4^{\text {th }}$ group) respectively (table 5).

Microscopic study of caecum showed that typical histological structure in all experimental groups was preserved. Mucous membrane was plicated, did not not form villi, was presented by epithelial layer, namely mucous membrane, muscular and submucous basis. Epithelial layer was one-layer columnar epithelium with big number of goblet cells. In submuscular layer formed lymph nodes have been detected (lymph follicles) (Fig. 12). Muscular membrane consisted of two layers of muscular fibres. Serous membrane had intensively developed connective layer covered by mesothelium.

Macroscopic study showed that in all experimental groups on the $42^{\text {nd }}$ and $70^{\text {th }}$ day liver was of typical anatomic structure, of homogeneous colouring (dark brown), with rims being acute, structure at cross cut being preserved and consistency being resilient. 
Table 5

Morphometric indices of mucous membrane of duodenum during whole test period $(\mathrm{M} \pm \mathrm{m}, \mathrm{n}=5)$

\begin{tabular}{llcc}
\hline \multicolumn{1}{c}{ Groups } & Villus height, $\mu \mathrm{m}$ & Crypt depth, $\mu \mathrm{m}$ & VH/CD ratio \\
\hline & \multicolumn{1}{c}{$42^{\text {nd }}$ day of test (70 days) } & \\
\hline Probion-forte, $1 \mathrm{~g} / \mathrm{kg}$ & $308.68 \pm 1.12^{*}$ & $30.74 \pm 0.34$ & $1: 0.099$ \\
Bio Plus 2B, $0.4 \mathrm{~g} / \mathrm{kg}$ & $307.62 \pm 1.31^{*}$ & $30.72 \pm 0.28$ & $1: 0.099$ \\
Control & $293.18 \pm 1.27$ & $30.08 \pm 0.25$ & $1: 1.102$ \\
\hline \multicolumn{1}{c}{$70^{\text {th }}$ day of test (98 days) } & $1: 0.073$ \\
\hline Probion-forte, $1.0 \mathrm{~g} / \mathrm{kg}$ & $488.32 \pm 1.18^{* *}$ & $35.91 \pm 0.31$ & $1: 0.070$ \\
Probion-forte, $0.5 \mathrm{~g} / \mathrm{kg}$ & $478.12 \pm 1.42^{* *}$ & $33.52 \pm 0.27$ & $1: 0.072$ \\
Bio Plus 2B, 0.4 g/kg & $473.12 \pm 1.24^{*}$ & $34.18 \pm 0.26$ & $1: 0.068$ \\
Control & $452.77 \pm 1.16$ & $31.03 \pm 0.22$ & \\
\hline
\end{tabular}

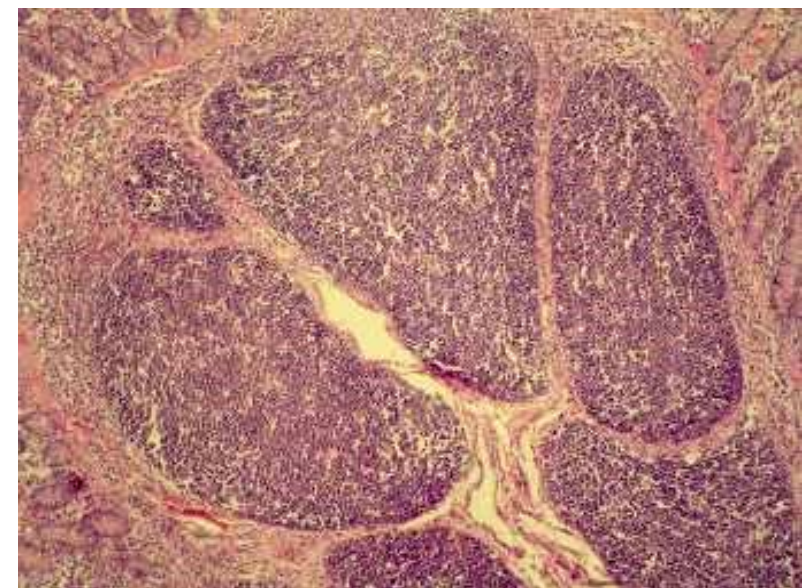

Fig. 12. Lymph follicles in caecal submucous layer of piglets from the $1^{\text {st }}$ group, $70^{\text {nd }}$ day of test. H\&E. x 100

Histological test of liver showed that in all treated groups on the $42^{\text {nd }}$ and $70^{\text {th }}$ day parenchyma is divided into lobes by connective septa. Hepatocytes are densely situated around central vein and form long, radially-oriente - hepatic plates. Liver cells are of polygonal form, nuclei are clearly outlined.

In the experimental and control groups on the $70^{\text {th }}$ day than on the $42^{\text {nd }}$ day we have detected nidus of discomplexation of joist structure, hepatocytes with heterogeneously stained, granular cytoplasm, poor colouring of nuclei, cells with signs of lysis. Histological structure of liver of experimental groups on the $70^{\text {th }}$ day of test is presented in Fig. 13.

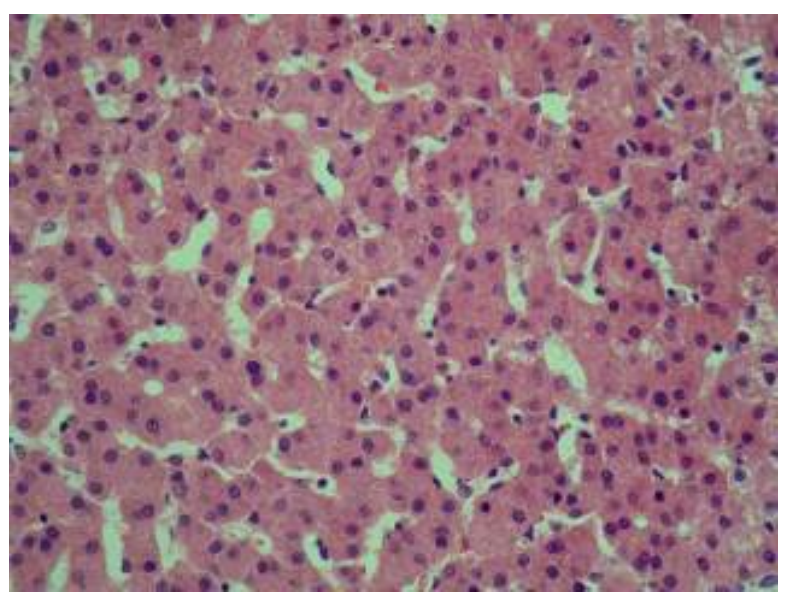

Fig. 13. Piglet liver, the $2^{\text {nd }}$ group, $70^{\text {nd }}$ day of test. Widening of internal lobular capillary blood vessels. H\&E. x 200

\section{Conclusions}

Clinical trials have shown that the use of Probion-forte, as a feed additive to piglets for fattening, within 10 weeks after weaning, did not cause adverse reactions, was well tolerated by animals and contributed to the improvement of the processes of erythropoiesis and leucopoiesis, increased the content of serum total protein. The activity of transaminases in serum indicated a more intense metabolic processes in the body of the experimental groups of animals, which was confirmed by an increase in average daily body weight gain and slaughter output compared to control.

In the microscopic examination of the thymus, spleen, lymph nodes, intestines, liver, the characteristic histological structure of the organs was preserved and indicated their active morphofunctional state throughout the study period. Morphometrically, the increase in the height of the villi in the duodenum and the size of the thymus lobes in piglets fed by probiotic feed additives was established. The efficiency and appropriateness of the application was confirmed in both the first and second study groups. However, the most significant difference was observed in piglets fed Probionforte for 10 weeks at a dose of $1.0 \mathrm{~g} / \mathrm{kg}$ of feed.

Prospects for further research: the study of the effect of different doses of probiotic feed additives on the microflora of the duodenum and cecum of pigs.

\section{References}

Anadon, A., Martinez-Larranaga, M., \& Aranzazu-Martinez, M. (2006). Probiotics for animal nutrition in the European Union. Regulation and Safety Assessment. Regulatory Toxicology and Pharmacology, 45(1), 91-95. doi: 10.1016/j.yrtph.2006.02.004.

Bliznetsov, A. V., \& Tokarev, I. N. (2013). Rezultaty ispolzovaniya probiotikov pri doraschivanii porosyat $\mathrm{v}$ usloviyah promyshlennoy tehnologii. Materialy mezhdunarodnoy nauchno-prakticheskoy konferentsii “Agrokompleks-2013”. Ufa, 1, 151-152 (in Russian).

Griggs, J. P., \& Jacob, J. P. (2005). Alternatives to antibiotics for organic poultry production. J. Appl. Poult. Res., 14(4), 750756. doi: 10.1093/japr/14.4.750.

Gutyj, B., Grymak, Y., Hunchak, V., Mysak, A., Nazaruk, N., Brezvyn, O., Hariv, I., Shcherbatyy, A., Semeniv, B., Bushueva, I., Parchenko, V., \& Kaplaushenko, A. (2018). Preclinical searches of the preparation Thireomagnile. Ukrainian Journal of Ecology, 8(1), 688-695. doi: 10.15421/2018_267.

Ievropeiska konventsiia pro zakhyst khrebetnykh tvaryn, shcho vykorystovuiutsia dlia doslidnykh ta inshykh naukovykh tsilei. Strassburh, 18 bereznia 1986 roku (in Ukrainian).

Kocjumbas, G. I., \& Lemishevskij, V. M. (2013). Gistostruktura i morfometricheskie pokazateli slizistoj obolochki zheludka svinej pri skarmlivanii kormov s razlychnim soderzhaniem 
probiotikov. Integracija nauki i praktiki kak mehanizm jeffektivnogo razvitija APK, 1, 204-206 (in Russian).

Kotsiumbas, I. Ia., Bisiuk, I. Yu., Horzheiev, V. M., \& Malyk, O. H. (2013). Klinichni doslidzhennia veterynarnykh preparativ ta kormovykh dobavok. L.: TOV Vydavnychyi dim „SAM” (in Ukrainian).

Kotsiumbas, I. Ya., Zhyla, M. I., \& Piatnychko, O. M. (2014). Imunotoksykolohichnyi kontrol veterynarnykh preparativ ta kormovykh dobavok: Metodychni rekomendatsii. Lviv (in Ukrainian).

Lisova, N. E., Schebentovska, O. M., Rudik, G. V., Maksimovich, O. A., Gumenetska, M. I., Kolodiy, G. V. (2013). Vplyv probiotykiv na imunnyi status ta morfofunktsionalnyi stan okremyh struktur shlunkovo-kyshkovogo traktu porosyat. Nauk.-tehn. Byul. Instytutu biolohiyi tvaryn i DNDKI vetpreparativ ta kormovykh dobavok, 14(3-4), 225-231 (in Ukrainian).

Malik, N. I., Panin, A. N., Vershinina, I. Ju. (2006). Probiotiki: teoreticheskie i prakticheskie aspekty. Veterinarija, 6, 48-50 (in Russian).

Merkulov, H. A. (1969). Kurs patolohohistolohicheskoi tekhniki [Course of pathohistological techniques]. Leningrad, Medicine Publ. (in Russian).

Patereha, I. P., Kushnir, V. I., Zhyla, M. I., \& Dubin, O. M. (2019). Acute and subacute toxicity of the drug based on tylosin tartrate. Scientific Messenger of Lviv National University of Veterinary Medicine and Biotechnologies. Series: Veterinary sciences, 21(94), 97-102. doi: 10.32718/nvlvet9418.

Patterson, J. A., \& Burkholder, K. M. (2003). Application of prebiotics and probiotics in poultry production. Poultry Science, 82(4), 627-631. doi: 10.1093/ps/82.4.627.

Reshetnichenko, O., Orlov, L., \& Kryukov, V. (2012). Probiotyky v godivli tvaryn. Tvarynnytstvo Ukrainy, 5, 25-29 (in Ukrainian).
Swiatkiewicz, S., \& Koreleski, J. (2007). Dodatki paszowe o dzialaniu immunomodulacyjnym w zywieniu drobiu. Medycyna Wet., 63(11), 1291-1295. http://www.medycynawet.edu.pl/ images/stories/pdf/pdf2007/112007/200711s12911295.pdf.

Todoriuk, V. B., Hunchak, V. M., Gutyj, B. V., Gufriy, D. F.,Hariv, I. I., Khomyk, R. I., \& Vasiv, R. O. (2018). Preclinical research of the experimental preparation "Ferosel $T$ ". Ukrainian Journal of Veterinary and Agricultural Sciences, 1(1), 3-9. doi: 10.32718/ujvas1-1.01.

Ushakova, N. A., Nekrasov, R. V., \& Pravdin, V. G. (2012). Novoe pokolenie probioticheskih preparatov kormovogo naznacheniya. The Fundamental Researches, 1, 184-192 (in Russian).

Zhyla, M. I. (2015). Histolohichna struktura okremykh vnutrishnikh orhaniv porosiat pry zastosuvanni probiotychnykh kormovykh dobavok. Biolohiia tvaryn, 17(1), 55-61. http://nbuv.gov.ua/UJRN/bitv_2015_17_1_10 (in Ukrainian).

Zhyla, M. I. (2017). Farmakolohichna ta klinikomorfolohichna otsinka imunomoduliuiuchykh i probiotychnykh zasobiv (klinichni doslidzhennia, dokumentatsiia, farmakolohichnyi kontrol efektyvnosti dii): avtoref. dys. na zdobuttia nauk. stupenia d-ra vet. nauk: 16.00.04 „Veterynarna farmakolohiia ta toksykolohiia” i 16.00.02 „Patolohiia, onkolohiia i morfolohiia tvaryn”. Lviv (in Ukrainian).

Zhyla, M. I., Patereha, I. P., Tomaszewska, E., Muszynski, S., Dobrowolski, P., Dubin, O. M., \& Koval, Y. B. (2019). Avaluation of morphofunctional condition of rats organism for study of toxicity of the preparation tilmicosine basis. Scientific Messenger of Lviv National University of VeterinaryMedicine and Biotechnologies. Series: Veterinary sciences, 21(95), 47-54. doi: 10.32718/nvlvet9509.

Zhyla, M. I., Shkodiak, N. V., Sobodosh, O. Y., \& Piatnychko O. M. (2014). Dynamika biokhimichnykh pokaznykiv krovi porosiat za umov zastosuvannia probiotychnykh preparativ. Naukovo-tekhnichnyi biuleten Instytutu biolohii tvaryn NAAN $i$ DNDKI vetpreparativ ta kormovykh dobavok, 15(4), 95-99 (in Ukrainian). 